International Journal of Current Microbiology and Applied Sciences

ISSN: 2319-7706 Volume 10 Number 10 (2021)

Journal homepage: http://www.ijcmas.com

\title{
Effect of Fermentation on the Biochemical Composition of Soybean (Glycine max L.) and Red Bean (Vigna unguiculata L.) Consumed in the City of Daloa (Côte d'Ivoire)
}

\author{
Yao N'zué Benjamin ${ }^{1}$, Ehouman Ano Guy Serge ${ }^{1}$, Adingra Kouassi Martial-Didier ${ }^{2}$, \\ Aka Kouakou Serge Phares ${ }^{1}$ and Tano Kablan ${ }^{2}$ \\ ${ }^{1}$ Department of Agroforestry, University Jean Lorougnon Guédé, BP 150 Daloa, Côte d'Ivoire \\ ${ }^{2}$ Department of Food Science and Technology, University Nangui Abrogoua, 02 BP 801 \\ Abidjan 02, Côte d'Ivoire \\ *Corresponding author
}

\section{A B S T R A C T}

Legumes are rich in protein. However, they are not consumed much because their consumption poses a problem of digestion due to anti-nutritional factors and

\section{Keywords}

Bean, Soybean, Spontaneous fermentation, Antinutritional factors, Nutritional quality

Article Info

\section{Accepted:} 18 September 2021 Available Online: 10 October 2021 consumers have a preference for proteins from livestock. It therefore appears useful to promote them. The means used to enhance them was fermentation. This technique improves the nutritional and biological qualities of legumes. The seeds of red bean (cowpea, Vigna unguiculata L.) and soybean (Glycine max L.) sold in the large market of Daloa (Côte d'Ivoire) constituted the biological material of this study. Thus, a spontaneous fermentation of the seeds of these legumes followed by the determination of biochemical parameters was carried out. During spontaneous fermentation, the nutritional value of fermented seed flours was improved by significantly decreasing $(\mathrm{P}<0.05)$ anti-nutritional factors. This reflects the impact of fermentation on improving the organic quality of these legumes. This study revealed that a 24 hour fermentation period is advisable for the population. This time allows keeping a good energy value, an acceptable level of nutrients although the fermentation after 72 hours considerably reduces the anti-nutritional compounds.

\section{Introduction}

Like most developing countries, Côte d'Ivoire has not escaped the phenomenon of galloping demographic growth in recent years (Fondio et al., 2013). In fact, the Ivorian population has grown to 22,671,331 inhabitants according to estimates by the National Institute of Statistics (INS) established in 2015 on the basis of the fourth General Population and Housing Census (RGPH) 2014. That is an average annual growth rate of $2.6 \%$ since 1998 (INS, 
2016).Unfortunately, this population growth is not followed by a proportional increase in agricultural food production. The balance between production and consumption is negative with a national average production of meat and fish of 104,254 tons against a total consumption of meat and fish of 371,475 tons. This clearly reflects the lack of national production of animal proteins for a population whose main protein source is animal (FAO, 2008). Like meat, fish and mushrooms; legumes are an important source of dietary protein. And this richness in protein makes legumes a protein source of plant origin which could be an alternative to the consumption of protein of animal origin. Thus, it is obvious that consuming legumes would ensure a regular supply of protein at low cost (BenSouilah, 2015).Among these grain legumes, red bean (Vigna unguiculata L.) and soybean (Glycine max L.) are species widely consumed by African populations. Its seeds are an important source of protein (20-25\%), fibers, carbohydrates (55-64\%), phenolic compounds and anti-nutritional factors such as phytates, tannins and oxalates (Andriantsoa, 2006; Labat, 2013). But, they are rich in B vitamins such as niacin, thiamine and riboflavin, as well as minerals (Anses, 2016; Rémond \& Walrand, 2017). They are used in many food preparations (FAO, 2016).However, all of this information on the nutritional potential of beans and soybeans relates only to grains in the raw state. There is still a lack of information to be filled, particularly in terms of the impact of processing technologies on the nutritional value of the seeds of these legumes. The nutritional quality of these legumes is strongly influenced by many factors including soaking, fermentation and cooking. With regard to soaking, work has shown that during this unitary operation, material transfers take place between the food compartment and the soaking water: some of the minerals diffuse into the surrounding environment as well as the activators and / or bioavailability inhibitors. In addition, fermentable sugars and some anti-nutritional elements disappear or are partially degraded (Andrianirina, 2015).As for cooking, research has shown that it significantly reduces almost all of the nutrients found in legumes except fibers (Tchumou, 2017). Today, a wide variety of fermented foods are produced and consumed around the world.

Fermentation takes place with plenty of water, about three times the volume of the seeds at room temperature. This operation makes it possible first of all to tenderize the raw material to facilitate subsequent grinding, secondly to dissolve and even eliminate the proteins responsible for flatulence as well as those producing the specific bitterness in legumes (Ranaivotrimo, 2015).

It can lead to a reduction in the levels of antinutritional factors and in particular phytates by $53 \%$ (voandzou) and 20-24\% (ambérique) (Rahelimandimby, 2011). This process has many advantages, including the reduction of the risk of development of pathogenic microorganisms by acidification of the medium, in addition to the degradation of antinutritional compounds (Nout, 1994; Blandino et al., 2003). In addition, several advantages seem to be associated with fermentation: the reduction by degradation of certain antinutritional factors, the enrichment of the product with nutrients beneficial to health, the reduction in the allergenicity of proteins, and the reduction in the $\alpha$ - galactosides content, whose fermentation in the colon is largely responsible for flatulence (Shimelis \& Rakshit, 2008; Kasprowicz-Potocka et al., 2016, Asres \& Nega, 2018).

Legumes contain anti-nutritional compounds that can act as a brake on their consumption. It is therefore necessary to better understand the fermentation mechanisms and processes that could reduce these anti-nutritional factors 
while preserving the nutritional value of beans and soybeans. It would be desirable to assess the effect of fermentation on the nutrient composition of these legumes. The aim of this study is to contribute to improving the nutritional, digestive and organoleptic quality of soybeans and beans consumed in Côte d'Ivoire.

\section{Materials and Methods}

The seeds of red bean (cowpea, Vigna unguiculata L.) and soybean (Glycine max L.) constituted the biological material of this study. The seeds were collected at the large market in Daloa (Côte d'Ivoire).

\section{Preparation of seeds before analyzes}

Two (2) kilograms of seeds of each legume (kidney bean and soybean) collected were first sorted to remove impurities and then divided into two lots. A batch unfermented and powdered for different strengths. The other batch went through different fermentations for up to 72 hours and then crushed into very fine particles for the different dosages. Fermentation was carried out in jars; per $100 \mathrm{~g}$ of seed $300 \mathrm{~mL}$ of water were added.

\section{Determination of physicochemical parameters}

The determination of humidity or dry matter was carried out by drying in an oven at $105^{\circ} \mathrm{C}$ for $24 \mathrm{~h}$ to constant weight (AOAC, 2000). The ash content was determined by incineration at $550{ }^{\circ} \mathrm{C}$ for $12 \mathrm{~h}$ according to the AOAC (2000) method. The $\mathrm{pH}$ of the sample was measured with a digital $\mathrm{pH}$ meter (Consort P107, Belgium) and the titratable acidity was determined using the method described by AOAC (2000) using sodium hydroxide solution $(\mathrm{NaOH})$, normal $0.1 \mathrm{~N}$, in the presence of phenolphthalein as color indicator.

\section{Determination of nutritional compounds}

Total lipids were determined by continuous extraction according to the Soxhlet method for 7 hours using hexane as solvent (AOAC, 2000). Total proteins were calculated from nitrogen $(\mathrm{N} \times 6.25)$ obtained by the method (AOAC, 1990) using Kjeldahl. The fibers content were determined according to the AOAC (1990) method.

Total and reducing sugars were determined respectively according to the method of Dubois (1956) using phenol and concentrated sulfuric acid and the method of Bernfeld (1955) using 3, 5-dinitrosalicylic acid (DNS). The total carbohydrate level was determined by calculation, according to the formulas described by Bertrand \& Thomas (1910):

Total carbohydrates $(\%)=100-(\%$ Moisture $+\%$ Protein $+\%$ Fat $+\%$ Ash)...(1)

The energy value was determined by calculation, according to the formula of Coleman (1970) using the coefficients of Atwater \& Rosa (1899)

E. $\mathrm{V}(\mathrm{Kcal})=(4 \mathrm{x} \%$ Protein $)+(4 \mathrm{x} \%$ Total Carbohydrates $)+(9 \times \%$ Fat $) ..(2)$

\section{Determination of anti-nutritional parameters}

\section{Oxalates}

The oxalate dosage was determined according to the method described by Day \& Underwood (1986). Two (2) g of each ground sample was homogenized in $75 \mathrm{~mL}$ of $\mathrm{H}_{2} \mathrm{SO}_{4}(3 \mathrm{M})$. The resulting mixture was stirred magnetically for $1 \mathrm{~h}$ at room temperature $\left(28{ }^{\circ} \mathrm{C}\right)$. The whole was filtered through Whatman $\mathrm{N}^{\circ} 4$ filter paper. Twenty-five (25) $\mathrm{mL}$ of filtrate was titrated hot with $0.05 \mathrm{M}$ potassium permanganate $\left(\mathrm{KMnO}_{4}\right)$ solution until a 
persistent pink turn. The oxalate content was obtained by the equation:

Oxalates $(\mathrm{mg} / 100 \mathrm{~g})=(2,2 \times$ Veq $\times$ $100) /$ me...(3)

Veq: volume $(\mathrm{mL})$ of $\mathrm{KMnO}_{4}$ poured in equivalently; me: mass $(\mathrm{g})$ of the sample.

\section{Phytates}

Phytates were determined according to the method of Latta \& Eskin (1980) using Wade's reagent. One gram of each ground sample was homogenized in $20 \mathrm{~mL}$ of $0.65 \mathrm{~N} \mathrm{HCl}$. The resulting mixture was stirred for $12 \mathrm{~h}$ at room temperature $\left(28{ }^{\circ} \mathrm{C}\right)$. The whole was centrifuged at $3000 \mathrm{rpm}$ for $40 \mathrm{~min}$. To 0.5 $\mathrm{mL}$ of the supernatant was added $3 \mathrm{~mL}$ of Wade's reagent. Then the tube was left to stand for $15 \mathrm{~min}$ in the dark and the absorbance reading was taken on a spectrophotometer (PG Instruments, England) at $490 \mathrm{~nm}$ against a blank. Finally, a calibration curve was produced using a range of phytic acid with a concentration of 0 to 10 $\mathrm{mg} / \mathrm{mL}$. The results were expressed as $\mathrm{mg}$ phytic acid equivalent (PAE)/100g of dry matter (DM).

\section{Tannins}

The tannins were assayed according to the method described by Bainbridge et al., (1996). A volume of $1 \mathrm{~mL}$ of methanolic extract from each sample (supernatant obtained from the extraction of polyphenols) was taken and to this volume was added $5 \mathrm{~mL}$ of vanillin reagent $(50 \mathrm{~g}$ of vanillin $+4 \mathrm{~mL}$ of acid hydrochloric acid in $100 \mathrm{~mL}$ of distilled water). Then the tube was left to stand for 20 min in the dark and the absorbance reading on a spectrophotometer (PG Instruments, England) was taken at $500 \mathrm{~nm}$ against the blank. Finally, a calibration curve was performed using a range of tannic acid with a concentration of 0 to $2 \mathrm{mg} / \mathrm{mL}$. The results were expressed in mg tannic acid equivalent (EAT)/100g of dry matter (DM).

\section{Statistical analysis}

Statistical analysis of the results was carried out using the STATISCA 7.1 software. Oneway analysis of variance (ANOVA) was performed to compare variables analyzed on samples during fermentation. The differences were considered significant for $p$ values $\leq$ 0.05. To separate the different samples, multiple comparison tests (Duncan) were carried out.

\section{Results and Discussion}

Effect of fermentation on the physicochemical parameters of beans and soybeans

Statistical analysis has shown that apart from increasing humidity, all measured parameter values decrease during fermentation. With regard to beans (Table 1), the $\mathrm{pH}$ decreased from $6.48 \pm 0.04$ to $3.91 \pm 0.01$ after 72 hours of fermentation. Titratable acidity and humidity increased respectively from $85.00 \pm$ 7.07 méq.g/100g to $220.00 \pm 0.00$ meq.g/100g and from $13.59 \pm 1.39 \%$ to $59.49 \pm 0.33 \%$ after 72 hours of fermentation. Similarly for soybeans, humidity increased from $10.06 \pm$ $0.07 \%$ to $62.19 \pm 0.33 \%$ after 72 hours of fermentation. On the other hand, the $\mathrm{pH}$ decreased from $6.46 \pm 0.01$ to $3.89 \pm 0.06$ and the titratable acidity oscillated between 70.00 \pm 0.00 and $180.00 \pm 0.00$ meq.g/100g after 72 hours of fermentation.

\section{Effect of Fermentation on Nutritional Compounds in Beans and Soybeans}

The results of the fermentation of the nutritional compounds of the seeds of the legumes studied are shown in Table 2 . Statistical analysis showed that the contents of nutritional compounds in the samples decreased as a function of the duration of the 
fermentation, apart from the rate of carbohydrates and energy value which increased proportionately. For beans, the contents of proteins, lipids, total fibers, ash and total sugars decreased respectively after 72 hours of fermentation from $21.14 \pm 0.06$ to $17.79 \pm 0.06 \%$, from $1.97 \pm 0.11$ to $1.14 \pm$ $0.04 \%$, from $17.51 \pm 0.70$ to $13.88 \pm 0.40 \%$, from $3.13 \pm 0.02 \%$ to $1.21 \pm 0.03 \%$ and from $1685.55 \pm 0.47$ to $279.23 \pm 1.18 \mathrm{mg} / 100 \mathrm{~g} \mathrm{MS}$. Carbohydrate level and energy value increased after 72 hours of fermentation respectively from $73.76 \pm 0.67$ to $79.86 \pm 0.39 \%$ and from $397.33 \pm 3.17$ to $400.86 \pm 1.55 \mathrm{Kcal} / 100 \mathrm{~g} \mathrm{MS}$. The content of reducing sugars increased from and from $116.11 \pm 0.79$ to $174.24 \pm 0.70$ $\mathrm{mg} / 100 \mathrm{~g}$ DM after 24 hours of fermentation to reach the value of $63.58 \pm 0.32 \mathrm{mg} / 100 \mathrm{~g} \mathrm{DM}$ after 72 hours of fermentation.

\section{Effect of Fermentation on Antinutrients in Beans and Soybeans}

The results shown in Table 3 indicate that the fermentation results in the reduction of the level of anti-nutritional compounds from the first day and continues over the fermentation time in the samples analyzed. With regard to beans, fermentation led to a decrease in the levels of oxalates, phytates and tannins respectively from $524.33 \pm 3.18$ to $104.33 \pm$ $3.18 \mathrm{mg}$ OAE/100g DM; from $37.00 \pm 0.29$ to $4.64 \pm 0.18 \mathrm{mg}$ PAE$/ 100 \mathrm{~g} \mathrm{DM}$ and from 34.82 \pm 0.22 to $7.23 \pm 0.16 \mathrm{mg}$ TAE$/ 100 \mathrm{~g} \mathrm{DM}$ after 72 hours of fermentation. As for soybean, the levels of oxalates, phytates and tannins varied from $495.00 \pm 0.00$ to $141.17 \pm 3.18 \mathrm{mg}$ OAE/100g DM, respectively; from $31.29 \pm$ 0.98 to $8.59 \pm 0.30 \mathrm{mg} \mathrm{PAE} / 100 \mathrm{~g}$ and from $29.54 \pm 0.31$ to $3.40 \pm 0.12 \mathrm{mg}$ TAE$/ 100 \mathrm{~g} \mathrm{DM}$ after 72 hours of fermentation.

Statistical analysis of the physico-chemical parameters measured on beans and soybeans that have undergone fermentation for $0 ; 24 ; 48$ and 72 hours has shown that apart from increasing humidity, all of the measured parameter values decrease during fermentation. The moisture contents of the soybean and bean samples before fermentation are $10.06 \%$ and $13.59 \pm 1.39 \%$, respectively. These values are similar to the values of the maximum humidity required for better preservation of dried seeds, which varies between 11 and 13\% (Agridea, 2007). This would mean that these dried legume seeds can be stored for a long time for later use. In addition, they are higher than the humidity levels obtained by Boyé et al., (2016) during their study on the agronomic and biochemical quality of a few varieties of cowpea from Côte d'Ivoire $(6.31 \%-9.33 \%)$. This difference could also be attributed to the preservation technique (solar drying in our case) and the conditioning of beans and soybeans sold on the market which are kept in bulk could be the subject of rehydration if the environment is favorable. During fermentation the water content of the seeds of these legumes increases considerably due to soaking which allows the seed to rehydrate due to the effect of fermentation which weakens the cotyledons of the seeds. In terms of $\mathrm{pH}$, the optimum $\mathrm{pH}$ range for the growth of yeasts and molds which is between 4 to 6.5 for yeasts and 4.5 to 6.8 for molds (Dilbaghi \& Sharma, 2007). At the start of fermentation, the $\mathrm{pH}$ of the beans and soybeans being included in this range will promote a gradual increase in the load of yeasts and molds. There was a gradual increase in the load of yeasts and molds. Indeed, the parameters influencing the growth of microorganisms in a food are the activity of the water, the $\mathrm{pH}$, the temperature and the composition of the food matrix (Blandino et al., 2003). After $72 \mathrm{~h}$ of spontaneous or natural fermentation of the seeds of these legumes, there is a considerable reduction in the $\mathrm{pH}$ of beans (3.91) and soybeans (3.89). These new $\mathrm{pH}$ values are no longer included in the optimum $\mathrm{pH}$ range for fungal growth because the conditions of the medium are not unfavorable to their growth. This would mean 
that the products resulting from the fermentation of these seeds after three days will be unlikely to fungal contamination. As the load of lactic acid bacteria and yeast increases, there is a production of organic acids by them. The production of organic acids in the medium leads to acidification of the medium, which is reflected in the increase in the titratable acidity of the seeds of fermented legumes after 24 hours of fermentation. Furthermore, the results of this study show that spontaneous fermentation has a considerable effect on the nutritional quality of beans and soybeans. During fermentation there is a reduction in protein content. This reduction in the protein content of these legume seeds after fermentation could be due to an increase in the catabolism of matrix proteins by the microorganisms during fermentation. Indeed, bacteria need nitrogenous substances to synthesize their proteins necessary for their growth. Some microorganisms have the ability to fix atmospheric nitrogen and others do not, such as lactic acid bacteria (Loubière et al., 1996). During their growth, microorganisms secrete proteases which will hydrolyze proteins into amino acids. Then, after the reactions of deamination of amino acids by deaminases, the microorganisms will assimilate nitrogen. This could lead to a drop in the nitrogen content in the matrix. These results are similar to those of Adegbehingbe (2014) who observed a reduction in protein content in lima bean seeds. Lipids are important compounds in the human diet and play several roles in the human body. Red lima beans are not high in fat. On the other hand, soybean, which is an oilseed, happens to be rich in proteins and lipids. During fermentation, there is a significant reduction in the lipid content. This reduction could be due to the hydrolysis of lipids by lipases produced by microorganisms during fermentation (Chada, 2019). As for total fiber, it decreases during the fermentation of the seeds of the legumes studied. This could be due to the secretion of extracellular enzymes such as ligninases, cellulases and hemicellulases by fungi (Oboh \& Elusiyah, 2007), capable of hydrolyzing crude fibers into simple sugars, which microorganisms could use as a source of carbon and transform them into other macromolecules such as proteins and fats (Oboh \& Akindahunsi, 2003).

Table.1 Evolution of the physico-chemical parameters of beans and soybeans during fermentation

\begin{tabular}{|c|c|c|c|}
\hline $\begin{array}{l}\text { Fermentation time } \\
\text { (hour) }\end{array}$ & pH & $\begin{array}{l}\text { Humidity } \\
(\%)\end{array}$ & $\begin{array}{c}\text { Titratable Acidity } \\
\text { (meq-g.100g) }\end{array}$ \\
\hline \multicolumn{4}{|c|}{ Bean } \\
\hline $\mathbf{0}$ & $6.48 \pm 0.04^{\mathrm{d}}$ & $13.59 \pm 1.39^{\mathrm{a}}$ & $85.00 \pm 7.07^{\mathrm{a}}$ \\
\hline 24 & $6.31 \pm 0.03^{c}$ & $55.23 \pm 0.01^{b}$ & $95.00 \pm 7.07^{\mathrm{ab}}$ \\
\hline 48 & $5.09 \pm 0.06^{b}$ & $58.17 \pm 0.03^{c}$ & $100.00 \pm 0.00^{b}$ \\
\hline 72 & $3.91 \pm 0.01^{\mathrm{a}}$ & $59.49 \pm 0.33^{\text {cd }}$ & $220.00 \pm 0.00^{c}$ \\
\hline \multicolumn{4}{|c|}{$\begin{array}{l}\text { Soybean } \\
\end{array}$} \\
\hline $\mathbf{0}$ & $6.46 \pm 0.01^{\mathrm{c}}$ & $10.06 \pm 0.07^{\mathrm{a}}$ & $70.00 \pm 0.00^{\mathrm{a}}$ \\
\hline 24 & $6.49 \pm 0.01^{c}$ & $56.88 \pm 0.05^{b}$ & $75.00 \pm 7.07^{\mathrm{ab}}$ \\
\hline 48 & $5.31 \pm 0.03^{b}$ & $60.16 \pm 0.23^{c}$ & $85.00 \pm 7.07^{b}$ \\
\hline 72 & $3.89 \pm 0.06^{\mathrm{a}}$ & $62.19 \pm 0.33^{\mathrm{d}}$ & $180.00 \pm 0.00^{c}$ \\
\hline
\end{tabular}

The values bearing the same letters in the column are not significantly different at the $5 \%$ level according to the DUNCAN test.

(0): Unfermented control. 
Table.2 Evolution of nutritional compounds in beans and soybeans during fermentation

\begin{tabular}{|c|c|c|c|c|c|c|c|c|}
\hline $\begin{array}{c}\text { Fermentatio } \\
\text { n time } \\
\text { (hour) }\end{array}$ & $\begin{array}{c}\text { Proteins } \\
(\%)\end{array}$ & $\begin{array}{c}\text { Lipids } \\
(\%)\end{array}$ & $\begin{array}{c}\text { Fibers } \\
(\%)\end{array}$ & $\begin{array}{c}\text { Carbohydra } \\
\text { te } \\
(\%)\end{array}$ & $\begin{array}{l}\text { Ash } \\
(\%)\end{array}$ & $\begin{array}{c}\text { Reducing } \\
\text { sugars } \\
(\mathrm{mg} / 100 \mathrm{~g})\end{array}$ & $\begin{array}{c}\text { Total } \\
\text { sugars } \\
(\mathbf{m g} / 100 g)\end{array}$ & $\begin{array}{c}\text { Energy } \\
\text { value } \\
\text { (kcal/100g) }\end{array}$ \\
\hline & \multicolumn{8}{|c|}{ Bean } \\
\hline $\mathbf{0}$ & $\begin{array}{c}21.14 \pm \\
0.06^{\mathrm{b}}\end{array}$ & $1.97 \pm 0.11^{b}$ & $17.51 \pm 0.70^{c}$ & $73.76 \pm 0.67^{a}$ & $3.13 \pm 0.02^{c}$ & $116.11 \pm 0.79^{d}$ & $\begin{array}{c}1685.55 \pm \\
0.47^{\mathrm{d}}\end{array}$ & $\begin{array}{c}397.33 \pm \\
3.17^{\mathrm{a}}\end{array}$ \\
\hline 24 & $\begin{array}{c}20.39 \pm \\
0.00^{b}\end{array}$ & $1.46 \pm 0.06^{\mathrm{a}}$ & $16.41 \pm 0.56^{\mathrm{bc}}$ & $76.64 \pm 0.48^{b}$ & $1.51 \pm 0.02^{b}$ & $174.24 \pm 0.70^{c}$ & $699.46 \pm 1.61^{\mathrm{c}}$ & $\begin{array}{c}401.26 \pm \\
2.22^{b}\end{array}$ \\
\hline 48 & $\begin{array}{c}18.48 \pm \\
0.00^{\mathrm{a}}\end{array}$ & $1.34 \pm 0.11^{\mathrm{a}}$ & $14.52 \pm 0.14^{b}$ & $\begin{array}{c}78.72 \pm \\
0.35^{\mathrm{bc}}\end{array}$ & $1.46 \pm 0.10^{b}$ & $71.01 \pm 0.67^{b}$ & $399.30 \pm 0.61^{b}$ & $\begin{array}{c}400.86 \pm \\
0.36^{\mathrm{b}}\end{array}$ \\
\hline \multirow[t]{2}{*}{72} & $\begin{array}{c}17.79 \pm \\
0.06^{\mathrm{a}}\end{array}$ & $1.14 \pm 0.04^{\mathrm{a}}$ & $13.88 \pm 0.40^{\mathrm{a}}$ & $79.86 \pm 0.39^{c}$ & $1.21 \pm 0.03^{\mathrm{a}}$ & $63.58 \pm 0.32^{\mathrm{a}}$ & $279.23 \pm 1.18^{\mathrm{a}}$ & $\begin{array}{c}400.86 \pm \\
1.55^{\mathrm{b}}\end{array}$ \\
\hline & \multicolumn{8}{|c|}{ Soybean } \\
\hline $\mathbf{0}$ & $33.88 \pm 00^{c}$ & $\begin{array}{c}19.31 \pm \\
0.42^{b}\end{array}$ & $16.24 \pm 0.32^{b}$ & $43.97 \pm 0.86^{\mathrm{a}}$ & $2.84 \pm 0.12^{c}$ & $95.20 \pm 0.32^{d}$ & $\begin{array}{c}1910.47 \pm \\
0.33^{\mathrm{d}}\end{array}$ & $\begin{array}{c}485.19 \pm \\
0.47^{\mathrm{c}}\end{array}$ \\
\hline 24 & $31.44 \pm 0.12^{b}$ & $\begin{array}{c}18.22 \pm \\
0.22^{\mathrm{a}}\end{array}$ & $15.63 \pm 0.12^{\mathrm{a}}$ & $48.95 \pm 0.02^{b}$ & $1.39 \pm 0.02^{b}$ & $159.47 \pm 1.03^{c}$ & $750.04 \pm 1.08^{c}$ & $\begin{array}{c}485.54 \pm \\
0.88^{\mathrm{c}}\end{array}$ \\
\hline 48 & $29.76 \pm 0.06^{\mathrm{a}}$ & $\begin{array}{c}17.15 \pm \\
0.56^{\mathrm{a}}\end{array}$ & $14.51 \pm 0.14^{\mathrm{a}}$ & $\begin{array}{c}51.92 \pm \\
0.72^{\text {bc }}\end{array}$ & $1.17 \pm 0.08^{a}$ & $37.77 \pm 0.17^{b}$ & $538.20 \pm 2.50^{b}$ & $\begin{array}{c}481.07 \pm \\
1.95^{\mathrm{b}}\end{array}$ \\
\hline 72 & $28.05 \pm 0.06^{\mathrm{a}}$ & $\begin{array}{c}16.11 \pm \\
0.11^{\mathrm{a}}\end{array}$ & $13.42 \pm 0.13^{\mathrm{a}}$ & $54.72 \pm 0.28^{c}$ & $1.12 \pm 0.02^{\mathrm{a}}$ & $21.38 \pm 0.13^{\mathrm{a}}$ & $262.13 \pm 1.00^{\mathrm{a}}$ & $\begin{array}{c}476.07 \pm \\
0.03^{\mathrm{a}}\end{array}$ \\
\hline
\end{tabular}

The values bearing the same letters in the column are not significantly different at the $5 \%$ level according to the DUNCAN test.

(0): Unfermented witness 
Table.3 Evolution of anti-nutritional compounds in beans and soybeans during fermentation

\begin{tabular}{|c|c|c|c|}
\hline Fermentation time (hour) & $\begin{array}{c}\text { Oxalates } \\
\text { (mg OAE/100g MS) }\end{array}$ & $\begin{array}{c}\text { Phytates } \\
\text { (mg PAE/100g MS) }\end{array}$ & $\begin{array}{c}\text { Tannins } \\
\text { (mg TAE/100g MS) }\end{array}$ \\
\hline \multicolumn{4}{|c|}{ Bean } \\
\hline $\mathbf{0}$ & $524.33 \pm 3.18^{\mathrm{d}}$ & $37.00 \pm 0.29^{\mathrm{d}}$ & $34.82 \pm 0.22^{\mathrm{c}}$ \\
\hline $\mathbf{2 4}$ & $249.17 \pm 15.88^{\mathrm{c}}$ & $16.11 \pm 0.73^{\mathrm{c}}$ & $14.60 \pm 0.69^{\mathrm{b}}$ \\
\hline $\mathbf{4 8}$ & $219.17 \pm 15.88^{\mathrm{b}}$ & $12.47 \pm 0.25^{\mathrm{b}}$ & $10.22 \pm 0.45^{\mathrm{a}}$ \\
\hline $\mathbf{7 2}$ & $104.33 \pm 3.18^{\mathrm{a}}$ & $4.64 \pm 0.18^{\mathrm{a}}$ & $7.23 \pm 0.16^{\mathrm{a}}$ \\
\hline \multicolumn{2}{|c|}{ Soybean $^{\text {Soyber|}}$} \\
\hline $\mathbf{0}$ & $495.00 \pm 0.00^{\mathrm{d}}$ & $31.29 \pm 0.98^{\mathrm{d}}$ & $29.54 \pm 0.31^{\mathrm{d}}$ \\
\hline $\mathbf{2 4}$ & $247.50 \pm 0.00^{\mathrm{c}}$ & $15.72 \pm 0.38^{\mathrm{c}}$ & $14.84 \pm 0.70^{\mathrm{c}}$ \\
\hline $\mathbf{4 8}$ & $220.00 \pm 0.00^{\mathrm{b}}$ & $11.16 \pm 0.40^{\mathrm{b}}$ & $10.34 \pm 0.26^{\mathrm{b}}$ \\
\hline $\mathbf{7 2}$ & $141.17 \pm 3.18^{\mathrm{a}}$ & $8.59 \pm 0.30^{\mathrm{a}}$ & $3.40 \pm 0.12^{\mathrm{a}}$ \\
\hline
\end{tabular}

The values bearing the same letters in the column are not significantly different at the $5 \%$ level according to the DUNCAN test.

(0): Unfermented witness

The carbohydrate content of legume seeds increased during fermentation. Indeed, this increase could be due to the decrease of other macronutrients that the microorganisms could consume during their growth.

The carbohydrate content is obtained by differential calculation and therefore if the other parameters decrease, it can only increase. In addition, it is important to specify that fibers occupy a good part of the total carbohydrates of the seeds of the legumes studied. The ash content decreases in the seeds studied during fermentation. The work of Aka et al., (2008) has shown that during the preparation of tchapalo, there is a decrease in the level of ash during the spontaneous fermentation of sorghum, an ingredient in the preparation of tchapalo. Difo et al., (2014) also observed a reduction in ash content during spontaneous fermentation of Vigna unguiculata flour. This reduction in ash content could result from the use of certain minerals by microorganisms for their metabolism. The total sugar content drops significantly $(\mathrm{P}<0.05)$ during fermentation. The reduction in soluble sugars content is thought to be due to their use as an energy source by microorganisms. For their metabolism, microorganisms can secrete enzymes which hydrolyze soluble sugars.

During the reduction of soluble sugars, it could have a significant reduction $(\mathrm{P}>0.05)$ in flatulence oligosaccharides. These results are similar to those of Assohoun et al., (2013) who observed a significant reduction $(\mathrm{P}<$ 0.05) in total sugar levels during the fermentation of corn for the production of doklu. During spontaneous or natural fermentation of beans or soya beans, there is a significant increase in the content of reducing sugars from 0 to 24 hours followed by a significant decrease $(\mathrm{P}<0.05)$ after 24 hours of fermentation. The increase in reducing sugars is due to the hydrolysis of starch by amylases, oligosaccharides, cellulose by cellulase produced by microorganisms (Xuemei et al., 2020). The reduction in the content of reducing sugars could be due to the use of these as a source of carbon by microorganisms during their metabolism. Cuellar-Álvarez et al., (2017) observed a significant increase $(\mathrm{P}<0.05)$ in the content of reducing sugars during spontaneous fermentation of seeds of Theobroma 
grandiflorum (Willd. Ex Spreng). Fermentation of protein-rich seeds such as soybeans and beans has resulted in protein degradation into amino acids and amylolytic degradation of carbohydrates into sugars and organic acids (Oluseyi \& Temitayo, 2015). Lipid is the main source of energy more than the energy provided by protein or carbohydrates (Pious \& Veerabahu, 2012). Thus, the richness of soybeans in lipids favored a higher energy value than that of beans. Flours obtained from the seeds of these two legumes could be beneficial to the body. Indeed, these fermented flours of these legumes could be used in part as energy flours in porridge for children if the quantity consumed per day is greater than $149 \mathrm{~g}$ because the child's energy needs vary from 547 to $1092 \mathrm{Kcal} /$ day (Butte, 1996). Fermentation resulted in an approximate $60 \%$ reduction in oxalate level and $80 \%$ tannin level reduction for all samples after 72 hours of fermentation. In fact, tannins and oxalates are mostly found in the peripheral parts of the grains (Lestienne, 2004). This high concentration of these compounds in the peripheral part of the grains causes their strong leaching during soaking. Thus, during soaking, material transfers take place between the food compartment and the soaking water. Part of the bioavailability inhibitors, which are the anti-nutritional compounds (tannins, phytates, oxalates) diffuse into the surrounding environment. These results agree with those of Murwan \& Ali (2011). They observed a reduction during spontaneous fermentation of the tannin content of two cultivars of sorghum (Dabar \& Tabat) in Sudan. Lewis \& Starkey (1968) indicated that the reduction in the tannin content of sorghum cultivars could be attributed to the activities of microorganisms during fermentation. During the activities of microorganisms, it might have a secretion of enzymes responsible for the degradation of tannins. The seeds of kidney beans and soybeans are rich in protein. The significant reduction in tannins contributes to improving the nutritional quality of the flour obtained from the seeds of these two fermented legumes by increasing the bioavailability of proteins. During fermentation, the oxalate content of fermented seeds decreases considerably. These results are similar with those of Oke \& Bolarinwa (2012) who observed a decrease in the oxalate content of taro flour (Colocasia esculenta) during its spontaneous fermentation. The marked reduction observed due to fermentation may be due to the effect of leaching and enzymatic hydrolysis / acid hydrolysis of the starch granule during fermentation. In addition, the decrease in the content of anti-nutritional compounds increases the bioavailability of minerals and consequently the nutritional value of the products.

Red beans and soybeans have high protein, carbohydrate and mineral content. These nutrients make these legumes almost complete foods and an alternative to protein sources of animal origin. Thus, it could be used in human food to solve the problems of protein-energy malnutrition. However, the high content of anti-nutritional factors developed during seed growth significantly decreases the nutritional value of these. Fermentation reduces the content of proteins, fibers, lipids, ash, minerals and increases those of carbohydrates and energy value. Although, some nutrients decrease during spontaneous fermentation, drastically reducing anti-nutritional factors such as phytates, tannins and oxalate improves the nutritional quality of the seeds. This improvement in the nutritional quality of these fermented seeds could make them valuable ingredients in human food.

\section{References}

Adegbehingbe, K. T., 2014. Effect of fermentation on nutrient composition and 
anti-nutrient contents of ground Lima bean seeds fermented with Aspergillus fumigatus, Rhizopus stolonifer and Saccharomyces cerevisiae. Int. J.Adv. Res., 2 (7) : 1208-1215.

Agridea, 2007.Soja, bio- Culture 4.7.1.p.6.

Aka, S., Djéni, N. T., N'guessan, K. F., Yao, K. C., and Dje, K. M., 2008.Variabilité des propriétés physico-chimiques et dénombrement de la flore fermentaire du tchapalo, une bière traditionnelle de sorgho en Côte d'Ivoire, Afr. sci., 4 (2): $274-286$.

Andrianirina, J., 2015. Caractérisations nutritionnelle et antinutritionnels des graines de légumineuses consommées dans l'Androy, $82 \mathrm{p}$.

Andriantsoa, Z. J., 2006. Evolution des facteurs anti nutritionnels de deux variétés de graines de niébé (Vigna unguiculata), Voanembafotsy et Voanemba mena, au cours de la germination. Mémoire pour l'obtention du diplôme d'étudesapprofondies de biochimie, $75 \mathrm{p}$.

ANSES (2016). Actualisation des repères du PNNS : élaboration des références nutritionnelles

AOAC, 1990. Méthodes officielles d'analyse. 15ème édition, Association des chimistes analytiques officiels, Washington, DC, États-Unis, pp. 200-210.

AOAC, 2000. Official methods of Analysis of AOAC International, 17th ed. AOAC International Washington, D C. 2200 p.

Asres, D. T., Nana, A., and Nega, G., 2018. Complementary feeding and effect of spontaneous fermentation on antinutritional factors of selected cerealbased complementary foods. $B M C$ Pediatrics, 18:394

Assohoun, M. C. N., Djeni, T. N., Koussémon-Camara, M., and Brou, K. 2013. Effect of Fermentation Process on Nutritional Composition and Aflatoxins Concentration of Doklu, a Fermented
Maize Based Food, FoodSci. Nutr., 4:1120-1127.

Atwater, W., and Rosa, E., 1899.A new respiratory calorimeter and the conservation of energy in human body. Physical Reviews Letters, 9: 214-251.

Bainbridge, Z., Tomlins, K., Willings, K., and Vestby, A., 1996. Methods for assessing quality characteristic of non-grain starch staple. Part 4 advanced methods. National ressources institute, University of Greenwich, 1:43-79.

Ben-Souilah, F., 2015. Caractérisation du comportement des micronutriments d'intérêt et des composes antinutritionnels des pois chiches et du niébé au cours des procédés de transformation. Mémoire de fin d'études. Université de Montpellier, Montpellier, France. 39 p.

Bernfeld, P., 1955. Amylase $\alpha$ and $\beta$ methods in enzymology 1. S. P. colowick and N.O. K, edition academic press, Inc New-York, 149-154 p.

Bertrand, G, and Thomas, P., 1910. Guide pour les Manipulations de Chimie Biologie.Dunod : Paris.

Blandino, A., Al-Aseeri, M. E., Pandiella, S. S., Cantero, D., Webb, C., 2003. Cerealbased fermented foods and beverages. Food Res. Int. 36: 527-543.

Boyé, M. A. D., Yapo, S. E. S, Koffi, N'. B. C., Koassi, N'. J., Tonessia, D. C., Soko, D. F., Ballo, E. K., Seu, J. G., Ayolié, K., and Kouadio, Y. J. 2016. Étude sur la qualité agronomique et biochimique de quelques variétés de niébé (Vigna Unguiculata L) Walp (Fabaceae) en provenance de la Côte d'Ivoire. ESJ, 12 (24) : 362-375.

Butte, N. F, 1996. Energy requirements of infants.Eur. J. Clin. Nutr., 50 Suppl 1 : 1876 S24-36.

Chada, L., 2019. Production améliorée des lipases à partir du Rhizopus oryzae NRRL 1526 en utilisant la biomasse 
lignocellulosique dans un milieu defermentation liquide. $53 \mathrm{p}$.

Coleman, C. H,. 1970. Calculations used in food analysis, In IFT World Directory guide. Publication of the Institute of Food Technologists: Chicago, Illinois USA; 326-331.

Cuellar-Álvarez, L., Cuellar-Álvarez, N, Galeano-García, P., and Suárez-Salazar J. C., 2017. Effect of fermentation time on phenolic content and antioxidant potential in Cupuassu (Theobroma grandiflorum (Willd. ex Spreng.) K.Schum.) beans. ActaAgron., 66 (4): 473-479.

Day, R. A., and Underwood, 1986.Quantitative analysis 5th ed., Prentice London, Hall Publication, 701.

Difo, H. V., Onyike, E., Ameh, D. A., Ndidi, U. S., and Njoku, G. C., 2014. Chemical Changes during Open and Controlled Fermentation of Cowpea (Vigna unguiculata) Flour. Int. J. Food Nutr.Saf., 5 (1): 1-10.

Dilbaghi, N., and Sharma, S., 2007. Food Spoilage, Food Infection and Intoxications Caused by Microorganisms and Methods for their Detection. 1-20.

Dubois, M., Gilles, K. A., Hamilton, J. D., Rebers, R. A., and Smith, M. 1956.Colometric method for determination of sugar and related substance. Anal. Chem., 28: 350-356.

FAO (2008). Etude du secteur avicole en Côte d'Ivoire, structure, importance et perspectives. Cas de l'aviculture semiindustrielle en Côte d'Ivoire. (Consulté le 16 décembre 2020). http://fao.org/browseIFB/* IF.

FAO, 2016. Légumineuses, des graines nutritives pour un avenir durable.196 p.

Fondio, L., Agbo A. E., Mabyao, A., N'zi, J. C., N'gbesso, M. F. D P., Djidji, A. H, and Kouame, C., 2013. Quelles contributions des légumes feuilles traditionnels à la sécurité alimentaire et à l'allègernent de la pauvreté des populations urbaines en Côte d'Ivoire ? Projet de Communication, $13 \mathrm{p}$.

INS (2016). Institut National de la Statistique (Consulté le 12 décembre 2020). http://www.ins.ci.

Kasprowicz-Potocka, M., Borowczyk, P., Zaworska, A., Nowak, W., Frankiewicz, A., and Gulewicz, P., 2016. The Effect of Dry Yeast Fermentation on Chemical Composition and Protein Value of Blue Lupin Seeds. Food Technol. Biotechnol., 54 (3): 1-17.

Labat, E., (2013). Le soja: influence de sa consommation sur la santé humaine et conséquences de l'expansion de sa culture au niveau mondial. Thèse pour le diplôme d'état de docteur en pharmacie, $104 \mathrm{p}$.

Latta, M., and Eskin, M., 1980. A simple and rapid method for phytate determination. J. Agric. Food Chem., 67: 1313-1315.

Lestienne, I., 2004. Contribution à l'étude de la biodisponibilité du fer et du zinc dans le grain de mil et conditions d'amélioration dans les aliments de complément. Thèse, Université de Montpellier II. 303p.

Lewis, A. J., and Starkey, R. L., 1968. Vegetable tannins, their decomposition and effects on decomposition of some organic compounds. Soil Sci, 4: 241-247

Loubière, P., Novak, L., Cocaign-Bousquet, M., and Lindley, N. D., 1996. Besoins nutritionnels des bactéries lactiques: interactions entre flux de carbone et d'azote. Le Lait, INRA Editions, 76 (12): 5-12.

Murwan, K., Sabah E., Ali, A., and AbdALRaheem, 2011.Effect of fermentation period on the chemical composition, invitro protein digestibility and tannin content in two sorghum cultivars (Dabar and Tabat) in Sudan. J. Appl. Biosci., 39: 2602- 2606.

Nout, M. J. R, 1994. Fermented foods and 
food safety. Food Res Int, 27: 291-298.

Oboh, G., and Akindahunsi, A. A., 2003. Biochemical changes in cassava products (flour and gari) subjected to Saccharomyces cerevisae solid media fermentation. Food Chem., 82: 599-602.

Oboh, G., and Elusiyan, C. A., 2007.Changes in the nutrient and anti-nutrient content of micro-fungi fermented cassava flour produced from low- and mediumcyanide variety of cassava tubers. Afr. J. Biotechnol., 6 (18): 2150- 2157.

Oke, M. O., and Bolarinwa, I. F., 2012.Effect of Fermentation on Physicochemical Properties and Oxalate Content of Cocoyam (Colocasia esculenta) Flour. ISRN Agronomy, 1:1-4.

Oluseyi, E. O., and Temitayo, O. M., 2015. Chemical and functional properties of fermented, roasted and germinated tamarind (Tamarindus indica) seed flours, Nutr. Food Sci., 45 (1): 97 - 111.

Pious, S. T., and Veerabahu, R. M., 2012. Comparative assessment on the nutritional and antinutritional attributes of the underutilized legumes, Canavalia gladiata (JACQ.) dc, Erythrina indica LAM. And Abrus precatorius L. Trop. Subtrop. Agroecosystems, 15: 539-556.

Rahelimandimby, H, 2011. Etude de la consommation des légumineuses dans les ménages d'Antananarivo et de l'influence des modes de préparation sur la réduction des teneurs en phytates, 115 p.

Ranaivotrimo, J. T., 2015. Valorisation de soja: «tofu, farine infantile » Etude de conservation du tofu et formulation de bouillie infantile à partir d'Okara pour enfant en sevrage. $148 \mathrm{p}$.

Rémond, D., and Walrand, S., 2017.Les graines de légumineuses: caractéristiques nutritionnelles et effets sur la santé. Innov. Agron., 60 : 133-144

Shimelis, E. A, and Rakshit, S. K., 2008. Influence of natural and controlled fermentations on $\alpha$-galactosides, antinutrients and protein digestibility of beans (Phaseolus vulgaris L.). Int. J. Food Sci. Technol., 43(4):658-65.

Tchumou, M., 2017. Enquête ethnobotanique et caractérisation physico-chimique des graines de haricot, Phaseolus lunatus (Fabaceae) consommées au Sud et à l'Est de la Côte d'Ivoire en fonction du niveau de maturité et du temps de cuisson, Thèse en Biochimie, $189 \mathrm{p}$.

Xuemei, W., Shikun, C., Zifu, L., Yu, M., and Jiajun, W., 2020. Impacts of Cellulase and Amylase on Enzymatic Hydrolysis and Methane Production in the Anaerobic Digestion of Corn Straw. Sustainability, 12 (5453): 1-11.

\section{How to cite this article:}

Yao N'zué Benjamin, Ehouman Ano Guy Serge, Adingra Kouassi Martial-Didier, Aka Kouakou Serge Phares and Tano Kablan. 2021. Effect of Fermentation on the Biochemical Composition of Soybean (Glycine max L.) and Red Bean (Vigna unguiculata L.) Consumed in the City of Daloa (Côte d'Ivoire). Int.J.Curr.Microbiol.App.Sci. 10(10): 572-583. doi: https://doi.org/10.20546/ijcmas.2021.1010.068 